\title{
PSIHOLOŠKI KAPITAL, SMISLENOST POSLA, ZADOVOLJSTVO POSLOM I DOBROBIT KOD NASTAVNIKA U PRIVATNIM I DRŽAVNIM ŠKOLAMA
}

\author{
Natalija Smrtić \\ Osnovna škola Odra Zagreb, Republika Hrvatska \\ Majda Rijavec \\ Učiteljski fakultet u Zagrebu, Sveučilište u Zagrebu, Republika Hrvatska
}

\begin{abstract}
Sažetak:
Cilj istraživanja bio je ispitati postoje li razlike u zadovoljstvu poslom, smislenosti posla, psihološkom kapitalu i dobrobiti kod nastavnika u privatnim i državnim školama. Nadalje, cilj je bio ispitati u kojoj mjeri zadovoljstvo poslom, smislenost posla i psihološki kapital doprinose dobrobiti zaposlenika u privatnim i državnim školama.Sudjelovalo je 152 nastavnika iz državnih te 100 nastavnika iz privatnih škola u Zagrebu. Kao mjerni instrumenti korišteni su skala smislenosti posla, upitnik psihološkog kapitala, skala zadovoljstva životom i skala psihološkog procvata. Globalno zadovoljstvo poslom mjereno je jednom česticom. Rezultati su pokazali da nema razlike između nastavnika u državnim i privatnim škola ni u jednoj ispitivanoj varijabli. Zadovoljstvo poslom pokazalo se kao značajan prediktor životnog zadovoljstva, dok se smislenost posla pokazala kao značajan prediktor psihološkog procvata. Psihološki kapital pozitivno doprinosi i zadovoljstvu životom i psihološkom procvatu. Rezultati istraživanja daju teorijski doprinos razumijevanju faktora dobrobiti nastavnika u državnim i privatnim školama, a mogu doprinijeti i osmišljavanju intervencija za stvaranje pozitivnog okruženja koje tu dobrobit poboljšava.
\end{abstract}

Ključne riječi: dobrobit, nastavnici u državnim i privatnim školama, smislenost posla, psihološki kapital, zadovoljstvo poslom

\section{UVOD}

S pojavom pozitivne psihologije sve je veći naglasak na istraživanjima organizacija u kojima ljudi uspješno rade, ali se i dobro osjećaju (Cameron, Dutton i Quinn, 2003; Luthans, 2002) što onda doprinosi i njihovoj općoj dobrobiti. Dobrobit je vrijedan cilj sam po sebi za sve zaposlenike, a u ovom radu naglasak će biti na dobrobiti nastavnika jer se pokazalo da je njihova dobrobit ujedno i važan čimbenik njihove učinkovitosti (Duckworth, Quinn, i Seligman, 2009). Pritom će se posebno istražiti razlika između nastavnika u državnim i privatnim školama. Naime, iako u Hrvatskoj djeluju i državne i privatne škole vrlo malo su istraživane razlike između njih kad su u pitanju različiti aspekti posla i dobrobit. Osim zadovoljstva poslom, za koje su dosadašnja istraživanja pokazala da je povezano s dobrobiti nastavnika, bit će uključene i varijable smislenosti posla kao i psihološkog kapitala na poslu jer se može pretpostaviti da u suvremenim uvjetima života ove varijable mogu dodatno doprinijeti dobrobiti nastavnika. 


\section{Dobrobit}

U području pozitivne psihologije dobrobit je mjerilo pozitivnog funkcioniranja pojedinca te vrijedan životni cilj (Rijavec, 2015). Ryan i Deci (2001) navode dva temeljna pristupa istraživanju dobrobiti - hedonistički i eudemonistički. Hedonistička ili subjektivna dobrobit definira se u terminima zadovoljstva te izbjegavanja neugode. Hedonistički pristup istraživanju dobrobiti usmjeren je na visoku razinu životnog zadovoljstva, visoku razinu pozitivnih i nisku razinu negativnih emocija (Tov i Diener, 2013). Uključuje kognitivnu i afektivnu komponentu, pri čemu se kao najčešće korišteni indikator kognitivne komponente koristi zadovoljstvo životom (Diener, Emmons, Larsen i Griffin, 1985), dok se afektivna komponenta odnosi na omjer pozitivnih i negativnih emocija (Watson, Clark i Tellegen, 1988). Eudemonistička ili psihološka dobrobit odnosi se na ostvarenje vlastitih potencijala (Ryan i Deci, 2001), a ovaj pristup istraživanju dobrobiti usmjeren je na smisao i samoostvarenje (Waterman, 1993). Kako bi se navedene komponente integrirale i promatrao njihov sinergijski učinak (Henderson i Knight, 2012), predložen je koncept psihološkog procvata (engl. flourishing). Huppert i So (2013) navode da psihološki procvat uključuje pozitivne karakteristike (emocionalna stabilnost, vitalnost, optimizam, otpornost, samopoštovanje), pozitivnu pobuđenost (zadovoljstvo životom i pozitivne emocije) te pozitivno djelovanje (angažiranost, kompetentnost, smislenost i pozitivni odnosi s drugima). Diener i suradnici (Diener i sur., 2010) definiraju flourishing kao psihosocijalni konstrukt koji uključuje pozitivne odnose, osjećaj kompetentnosti i samopouzdanja te vjerovanje da je naš život smislen i da ima neku svrhu. U radu će se ispitati životno zadovoljstvo kao kognitivna komponenta hedonističke dobrobiti i psihološki procvat kao kombinacija hedonističke i eudemonističke dobrobiti, kao i faktori koji se odnose na posao koji im doprinose u državnim i privatnim školama.

\section{Zadovoljstvo poslom}

Zadovoljstvo poslom definira se kao „pozitivan stav o vlastitom poslu koji proizlazi iz ocjena karakteristika posla“ (Robbins i Judge, 2010, str. 78). Prema Faragheru, Cassu i Cooperu (2005) zaposlenici s višim razinama zadovoljstva poslom imaju bolje mentalno i fizičko zdravlje, veće samopoštovanje, doživljavaju manje sagorijevanja na poslu te su manje depresivni i anksiozni od zaposlenika koji su u prosjeku manje zadovoljni svojim poslom. Rezultati metaanalize koju su proveli Bowling, Eschleman i Wang (2010) pokazuju da su osobe koje su zadovoljnije poslom istodobno zadovoljnije i životom općenito, sretnije te iskazuju više pozitivnih, a manje negativnih emocija, dakle imaju veću razinu subjektivne dobrobiti.

\section{Smislenost posla}

Smislenost posla moguće je definirati kao količinu značenja i svrhe koju ljudi vide u svom radu (Rosso, Dekas i Wrzesniewski, 2010). Kada pojedinac na radnom mjestu ne nalazi smisao, javlja se nedostatak zadovoljstva poslom, negativno poimanje sebe, smanjena organizacijska učinkovitost (Steenkamp i Basson, 2013) te depresivnost (Allan, Dexter, Kinsey i Parker, 2016). $S$ druge strane, smislenost posla doprinosi zadovoljstvu životom (Compton, 2000). Osobe koje su zadovoljnije poslom i koje u njemu vide smisao doživljavaju manje stresa i manje su anksiozne $u$ odnosu na one koje ne vide smisao i nisu zadovoljne svojim poslom (Allan i sur., 2016). Također, smislenost posla daje zaposlenicima osjećaj ispunjenosti i svrhe što doprinosi njihovoj psihološkoj dobrobiti (Whittington, Meskelis, Asare i Beldona, 2017).

\section{Psihološki kapital}

Psihološki kapital definira se kao pozitivno psihološko stanje razvoja osobe koje uključuje četiri psihološke varijable: samoefikasnost, nadu, optimizam i psihološku otpornost koje 
su u međusobnoj sinergiji (Luthans, Youssef i Avolio, 2007). Samoefikasnost predstavlja uvjerenje osobe u vlastite sposobnosti, tj. uvjerenje da svojim vještinama i znanjima može ostvariti neki cilj; Nada se definira kao kognitivno stanje u kojem je osoba sposobna postaviti realne i izazovne ciljeve, a zatim biti uporna u njihovom ostvarivanju (i, prema potrebi, modificirati putove koji do njih vode). Optimizam uključuje opće očekivanje pozitivnih ishoda i pozitivne atribucije uspjeha. Pritom optimizam kao pozitivno očekivanje (dispozicijski optimizam) označava očekivanje osobe da će se joj se u životu dogoditi više dobrih stvari u odnosu na loše, dok optimizam kao atribucijski stil uključuje uvjerenje da pozitivni događaji počivaju na unutarnjim, trajnim i globalnim uzrocima, dok su negativni događaji uzrokovani vanjskim, privremenim i specifičnim uzrocima. Psihološka otpornost odnosi se na sposobnost oporavka pojedinca od teških životnih situacija i nedaća, ali i od pozitivnih promjena, napretka ili povećane odgovornosti.

Luthans, Avolio, Avey i Norman (2007) navode da je psihološki kapital bolji pozitivni prediktor radnog učinka i zadovoljstva poslom nego njegove pojedinačne sastavnice. Psihološki kapital povećava angažiranost zaposlenika (Costantini i sur., 2017) te smanjuje stres i anksioznost (Avey, Reichard, Luthans i Mhatre, 2011). Nadalje, osobe s višom razinom psihološkog kapitala smatraju svoju učinkovitost na poslu većom, rjeđe daju otkaz, sretnije su na poslu i pokazuju višu subjektivnu dobrobit u odnosu na osobe s nižom razinom psihološkog kapitala (Avey i sur., 2011; Choi i Lee, 2014; Murgić, Rijavec i Miljković, 2019) kao i višu psihološku dobrobit (Li, 2018).

\section{Razlike između državnih i privatnih škola}

Prema Bakotić i Bušić (2014) privatne organizacije u vlasništvu su privatnih osoba koje ih pokreću i financiraju. Tvrtke u privatnom sektoru mogu biti male tvrtke kojima upravlja samo jedna osoba ili velike multinacionalne tvrtke čije je poslovanje rašireno diljem svijeta. S druge strane, javni sektor uključuje državna, regionalna i lokalna tijela, javne tvrtke, javne financijske institucije koje se financiraju iz državnog i/ili lokalnog i regionalnog proračuna. Jedne od institucija koje posluju i u javnom i u privatnom sektoru su škole. U Hrvatskoj prema Državnom zavodu za statistiku RH (2018) djeluju državne škole koje su osnovane od strane Republike Hrvatske te jedinica lokalne i regionalne samouprave kao i privatne škole čiji su osnivači fizičke i pravne osobe te vjerske zajednice.

Istraživanja razlika u dobrobiti nastavnika u privatnim i državnim školama vrlo su rijetka i ne pokazuju konzistentne rezultate. Tako, primjerice, Yılmaz i Şahin (2009) navode kako su životom zadovoljniji nastavnici u privatnim školama u odnosu na one u državnima. Slično je i kad je u pitanju zadovoljstvo poslom. U Hrvatskoj Žužić i Miljković Krečar (2014) nisu pronašli razlike u zadovoljstvu poslom između nastavnika na privatnom i državnom visokom učilištu (osim što su nastavnici na privatnom visokom učilištu bili zadovoljniji svojim suradnicima). Također, nije pronađena očekivana razlika u zadovoljstvu plaćom između učilišta. Za razliku od tog istraživanja Baş i Ardıç (2002) pokazali su da su visokoškolski nastavnici na privatnom fakultetu zadovoljniji poslom od nastavnika na državnom fakultetu. Tummers i Knies (2013) navode kako zaposleni u državnom sektoru ne mogu zbog dvosmislenosti i složenosti ciljeva pronaći smisao u onome što rade dok se, s druge strane, neki zapošljavaju upravo u državnim organizacijama jer tako žele dati smisao i značenje svom poslu. U državnim organizacijama dobri odnosi zaposlenika s nadređenima pozitivno su povezani sa smislenosti posla. $U$ privatnim školama smislenosti posla doprinosi obogaćivanje posla i stupanj u kojem se osoba poistovjećuje s radnom ulogom (Janik i Rothmann, 2015). Međutim, istraživači se do sada nisu bavili usporedbom smislenosti posla nastavnika u privatnim i državnim institucijama.

Shahnawaz i Hassan Jafri (2009) proučavali su psihološki kapital u privatnim i javnim tvrtkama. Rezultati istraživanja pokazali su da zaposlenici u privatnom sektoru pokazuju više razine optimizma i nade te niže razine samoefikasnosti u odnosu na javni sektor. Karmakar 
(2016) također navodi da se osobe iz privatnih organizacija u prosjeku više nadaju i optimističniji su, ali iskazuju i višu samoučinkovitost u odnosu na javni sektor. No, kao i kod smislenosti posla nije bilo istraživanja razlika između državnih i privatnih škola.

\section{Cilj istraživanja}

Istraživanja pokazuju kako su zadovoljstvo poslom, smislenost posla i psihološki kapital na poslu povezani s mentalnim zdravljem, srećom i zadovoljstvom u drugim područjima života pojedinca (Compton, 2000; Hansen, Buitendach i Kanengoni, 2015). Međutim, ne postoji istraživanje koje bi objedinilo navedene konstrukte te ih povezalo s različitim vrstama dobrobiti kod nastavnika i usporedilo s obzirom na privatni i javni sektor. Stoga je cilj ovog istraživanja ispitati postoje li razlike u zadovoljstvu poslom, smislenosti posla, psihološkom kapitalu na poslu te dobrobiti kod nastavnika u privatnim i državnim školama te u kojoj mjeri ove varijable doprinose dobrobiti zaposlenika u tim školama.

Očekuje se da će nastavnici u privatnim školama imati veću razinu psihološkog kapitala i veću dobrobit od nastavnika u državnim školama. S obzirom na ranija istraživanja nije moguće predvidjeti razlike u smislenosti posla i zadovoljstvu poslom s obzirom na vrstu škole. Nadalje, imajući u vidu teorijske pristupe dobrobiti, očekuje se da će zadovoljstvo poslom biti prediktor životnog zadovoljstva (jer su obje varijable indikatori subjektivne dobrobiti). S druge strane, smislenost posla će biti prediktor psihološkog procvata jer su smisao i svrha jedna od komponentni psihološkog procvata. Kad je u pitanju psihološki kapital, očekuje se pozitivan doprinos i životnom zadovoljstvu i psihološkom procvatu jer su komponente psihološkog kapitala teorijski povezane s objema vrstama dobrobiti.

\section{Metoda}

\section{Sudionici i postupak}

$\mathrm{U}$ istraživanju su sudjelovala 152 nastavnika iz državnih srednjih škola (110 žena i 38 muškaraca) te 100 nastavnika iz privatnih srednjih škola (67 žena i 32 muškarca). Kriterij za uključivanje privatnih srednjih škola bio je da su osnovane od pravnih ili fizičkih osoba, a ne vjerskih zajednica s pravom javnosti. Kod odabira škola vodilo se računa da i državne i privatne škole budu istog usmjerenja. Problem se pojavio jer su privatne škole uglavnom gimnazije, ekonomske, glazbene i sportske. Stoga su u oba sektora odabrane gimnazije i strukovne ekonomske škole. Od državnih škola odabrane su dvije gimnazije različitih usmjerenja (klasična i opća) i dvije strukovne škole ekonomskog usmjerenja. Među privatnim školama također su odabrane škole klasičnog i općeg usmjerenja te ekonomske škole, ali zbog manjeg broja nastavnika bilo je ukupno sedam škola. Prosječna dob nastavnika u državnim školama je 42,8 godina, a u privatnim 39 godina.

Provođenje istraživanja odobrilo je Povjerenstvo za rješavanje etičkih pitanja Odjela za psihologiju Hrvatskog katoličkog sveučilišta. U 4 državne srednje škole te 7 privatnih škola u Zagrebu ispitivanje je uz odobrenje ravnatelja provedeno metodom papir - olovka na sjednicama Učiteljskih vijeća. Prije samog ispunjavanja upitnika sudionici su pročitali informirani pristanak kojim im se objasnilo da je istraživanje dobrovoljno te da u bilo kojem trenutku mogu odustati. U istraživanju su sudjelovali svi nastavnici odabranih škola koji su tijekom provođenja istraživanja bili nazočni na sjednicama. 
Natalija Smrtić, Majda Rijavec

PSIHOLOŠKI KAPITAL, SMISLENOST POSLA, ZADOVOLSTVO.

\section{Instrumenti}

a) Skala zadovoljstva životom (engl. Satisfaction with Life Scale - SWLS; Diener i sur., 1985, hrvatski prijevod Rijavec, Brdar, Miljković, 2006) mjeri kognitivnu komponentu subjektivne dobrobiti (primjer tvrdnje: „Moj je život vrlo blizu onome što smatram idealnim“). Sastoji se od pet tvrdnji, a sudionici na skali od 1 do 7 stupnjeva procjenjuju koliko se slažu sa svakom navedenom tvrdnjom s time da 1 označava uopće se ne slažem, a 7 posve se slažem. Ukupni rezultat definira se kao prosjek odgovora na svim česticama. Viši rezultat ukazuje na veće zadovoljstvo životom odnosno veću subjektivnu dobrobit. Eksploratornom faktorskom analizom u ovom istraživanju utvrđeno je postojanje jednog faktora. Pouzdanost skale mjerena Cronbachovim $\alpha$ koeficijentom iznosi $\alpha=0,86$.

b) Skala psihološkog procvata (eng. Flourishing Scale - FS; Diener i sur., 2010, hrvatski prijevod Rijavec, Ljubin Golub i Olčar, 2016) mjeri percepciju uspješnosti pojedinca u području odnosa s drugim ljudima, samopoštovanja, svrhe i optimizma (primjer tvrdnje: „Moje svakodnevne aktivnosti me zanimaju i angažiran sam u njima"). Sastoji se od osam tvrdnji, a sudionici na skali od 1 do 7 stupnjeva procjenjuju koliko se slažu sa svakom navedenom tvrdnjom, pri čemu 1 označava uopće se ne slažem, a 7 posve se slažem. Ukupni rezultat čini prosjek zbroja procjena na svim česticama. Viši rezultat označava bolju percepciju funkcioniranja u različitim područjima života pojedinca, a samim time i veću psihološku dobrobit. Eksploratornom faktorskom analizom utvrđeno je postojanje jednog faktora. Pouzdanost skale mjerena Cronbachovim $\alpha$ koeficijentom iznosi $\alpha=0,84$.

c) Upitnik psihološkog kapitala (engl. PsyCap Questionnaire - PCQ; Luthans i sur., 2007, hrvatski prijevod Murgić, Rijavec i Miljković, 2019) ima 24 tvrdnje. Mjeri pozitivno psihološko stanje razvoja, a sastoji se od četiri subskale koje se odnose na četiri dimenzije psihološkog kapitala na poslu: samoefikasnost, nadu, psihološku otpornost i optimizam. Primjer čestice za ispitivanje samoefikasnosti glasi: „Siguran/na sam u sebe kada trebam analizirati dugoročne probleme kako bih za njih pronašao/la rješenje.“; nade: „Kada bih se našao/la u problemima na poslu, znam da bih pronašao/la više načina kako da se iz njih izvučem."; psihološke otpornosti: „Kada na poslu doživim neuspjeh, teško mi se oporaviti i opet krenuti naprijed." te optimizma: „Kad stvari na poslu postanu nesigurne, obično očekujem najbolje." Sudionici procjenjuju u kojoj se mjeri slažu sa svakom tvrdnjom na skali od 1 do 7 stupnjeva, pri čemu 1 znači uopće se ne slažem, a 7 upotpunosti se slažem. Svaka sastavnica psihološkog kapitala sastoji se od 6 čestica. Pouzdanost ljestvice mjerena Cronbachovim a koeficijentom iznosi $\alpha=0,91$. Eksploratornom faktorskom analizom (analiza glavnih komponenti) s kosokutnom (Direct oblimin) rotacijom utvrđeno je postojanje četiri faktora. Budući da su tri negativno formulirane tvrdnje imale opterećenja na više faktora („Kada na poslu doživim neuspjeh, teško mi se oporaviti i opet krenuti naprijed.“, „Ako mi se na poslu može dogoditi nešto loše, to će mi se baš i dogoditi.“, „Na ovom poslu stvari se nikada ne dogode onako kako bih ja želio."), remetile su faktorsku strukturu pa su izostavljene iz daljnje analize. Ukupni rezultat čini prosjek zbroja procjena na svim česticama. Budući da su prema Luthansu i sur. (2007) u podlozi svih navedenih četiriju faktora isti mehanizmi, a uz to Murgić i sur. (2019) navode da je psihološki kapital bolji prediktor kriterijskih varijabli nego njegove pojedinačne sastavnice, predlaže se uzimanje psihološkog kapitala kao faktora višeg reda te je u ovom istraživanju korišten ukupni rezultat. Viši rezultat ukazuje na višu razinu psihološkog kapitala.

d) Skala smislenosti posla (engl. Work Meaningfulness Scale; Bunderson i Thompson, 2009, hrvatski prijevod Miljković, Jurčec i Rijavec, 2016) mjeri percipirani smisao posla nastavnika. Sastoji se od pet tvrdnji, a sudionici na skali od 1 do 5 stupnjeva procjenjuju koliko se slažu sa svakom navedenom tvrdnjom, pri čemu 1 znači uopće se ne slažem, a 5 u potpunosti se slažem. Primjer čestice glasi: „Posao koji radim je važan.“ Ukupni rezultat čini prosjek zbroja procjena na svim česticama. Viši prosječni rezultat ukazuje na veću smislenosti posla. 
Eksploratorna faktorska analiza pokazala je postojanje jednog faktora. Pouzdanost skale mjerena Cronbachovim $\alpha$ koeficijentom je $\alpha=0,89$.

e) $U$ istraživanju je korišten globalni pristup ispitivanja zadovoljstva poslom pri čemu je navedeni konstrukt mjeren jednom česticom (Robbins i Judge, 2010). Sudionici su na Likertovoj skali od 1 do 7 procjenjivali u kojoj su mjeri općenito zadovoljni svojim poslom pri čemu 1 označava potpuno nezadovoljstvo, a 7 potpuno zadovoljstvo. Također, sudionici su navodili i demografske podatke o rodu, godinama radnog staža te vrsti škole u kojoj su zaposleni.

\section{ReZULTATI}

Kolmogorov-Smirnov test za normalnost distribucije pokazao je da se u državnim školama sve distribucije prikazanih varijabli statistički značajno razlikuju od normalne $(p<0,01)$, dok je u privatnim školama isti slučaj za sve varijable osim ukupnog psihološkog kapitala $(p>0,01)$. Međutim, i manja odstupanja od normalne distribucije obično su značajna na velikim uzorcima pa su za kriterij normalnosti korišteni indeksi asimetričnosti i spljoštenosti. Indeksi su se kretali u rasponu od -1.04 do 1.70 što su prihvatljive vrijednosti.

U Tablici 1. prikazani su deskriptivni podaci za ispitivane varijable u državnim i privatnim školama. Rezultati t-testa pokazuju da ne postoji statistički značajna razlika u ukupnom psihološkom kapitalu, smislenosti posla, zadovoljstvu poslom, zadovoljstvu životom te psihološkom procvatu između nastavnika državnih i privatnih škola.

Tablica 1. Razlike u psihološkom kapitalu, zadovoljstvu poslom, smislenosti posla te dobrobiti nastavnika između privatnih i državnih škola

\begin{tabular}{|c|c|c|c|c|c|c|c|c|c|c|}
\hline & \multicolumn{3}{|c|}{$\begin{array}{l}\text { Državne škole } \\
\qquad(N=152)\end{array}$} & & \multicolumn{3}{|c|}{$\begin{array}{l}\text { Privatne škole } \\
\qquad(N=100)\end{array}$} & \multirow[b]{2}{*}{ Max } & \multirow[b]{2}{*}{$t$} & \multirow[b]{2}{*}{$p$} \\
\hline & $M$ & $S D$ & Min & Max & $M$ & $S D$ & Min & & & \\
\hline Staž & 16,41 & 11,58 & 0,00 & 41,00 & 12,8 & 9,06 & 1,00 & 34,00 & & \\
\hline $\begin{array}{l}\text { Ukupni psihološki } \\
\text { kapital }\end{array}$ & 4,85 & 0,58 & 2,82 & 6,00 & 4,88 & 0,54 & 3,06 & 5,88 & 0,33 & 0,74 \\
\hline Nada & 4,87 & 0,62 & 2,33 & 6,00 & 4,9 & 0,69 & 2,50 & 6,00 & 0,28 & 0,78 \\
\hline Samoefikasnost & 4,84 & 0,69 & 2,83 & 6,00 & 4,99 & 0,68 & 2,83 & 6,00 & 1,74 & 0,08 \\
\hline Otpornost & 4,92 & 0,67 & 2,60 & 6,00 & 4,97 & 0,60 & 3,20 & 6,00 & 0,62 & 0,53 \\
\hline Optimizam & 4,78 & 0,74 & 2,50 & 6,00 & 4,65 & 0,82 & 2,25 & 6,00 & 1,35 & 0,18 \\
\hline Smislenost posla & 4,48 & 0,54 & 2,40 & 5,00 & 4,41 & 0,63 & 2,40 & 5,00 & 0,95 & 0,34 \\
\hline $\begin{array}{l}\text { Zadovoljstvo } \\
\text { poslom }\end{array}$ & 5,31 & 1,1 & 2,00 & 7,00 & 5,16 & 1,15 & 1,00 & 7,00 & 0,99 & 0,32 \\
\hline $\begin{array}{l}\text { Zadovoljstvo } \\
\text { životom }\end{array}$ & 5,23 & 1,06 & 1,40 & 7,00 & 5,15 & 1,01 & 1,60 & 7,00 & 0,63 & 0,53 \\
\hline $\begin{array}{l}\text { Psihološki } \\
\text { procvat }\end{array}$ & 5,79 & 0,73 & 3,50 & 7,00 & 5,82 & 0,58 & 3,88 & 6,88 & 0,45 & 0,66 \\
\hline
\end{tabular}

$N$ - broj sudionika, Min - minimalni rezultat, Max - maksimalni rezultat, $M$ - aritmetička sredina, $S D$ - standardna devijacija, $\mathrm{t}$ - vrijednost t-teta, $\mathrm{p}$ - razina značajnosti 
Natalija Smrtić, Majda Rijavec

Za utvrđivanje postojanja statistički značajne povezanosti između ispitivanih varijabli izračunati su koeficijenti korelacije među varijablama za državne i privatne škole (Tablica 2.).

Vidljivo je da i u privatnim i u državnim školama postoje značajne umjerene pozitivne korelacije između indikatora dobrobiti i zadovoljstva poslom, smislenosti posla i psihološkog kapitala.

Tablica 2. Korelacije među ispitivanim varijablama u državnim i privatnim školama

\begin{tabular}{|l|c|c|c|c|c|c|c|}
\hline & 1 & 2 & 3 & 4 & 5 & 6 & 7 \\
\hline 1. Rod & - & 0,10 & $-0,02$ & 0,08 & 0,05 & 0,07 & 0,19 \\
\hline 2. Staž & $0,27^{* *}$ & - & $-0,03$ & 0,02 & 0,20 & 0,04 & 0,00 \\
\hline 3. Ukupni psihološki kapital & $-0,05$ & 0,03 & - & $0,41^{* *}$ & $0,42^{* *}$ & $0,30^{* *}$ & $0,51^{* *}$ \\
\hline 4. Smislenost posla & 0,11 & 0,03 & $0,33^{* *}$ & - & $0,52^{* *}$ & $0,30^{* *}$ & $0,29^{* *}$ \\
\hline 5. Zadovoljstvo poslom & 0,04 & $-0,07$ & $0,44^{* *}$ & $0,51^{* *}$ & - & $0,47^{* *}$ & $0,34^{* *}$ \\
\hline 6. Zadovoljstvo životom & 0,05 & $-0,10$ & $0,50^{* *}$ & $0,18^{*}$ & $0,42^{* *}$ & - & $0,48^{* *}$ \\
\hline 7. Psihološki procvat & 0,09 & $-0,09$ & $0,66^{* *}$ & $0,38^{* *}$ & $0,49^{* *}$ & $0,67^{* *}$ & - \\
\hline
\end{tabular}

Napomena: iznad dijagonale su podaci za privatne, a ispod dijagonale za državne škole

${ }^{*} p<0,05 * * p<0,01$; Rod: muški - 1, ženski - 2

\section{Prediktori životnog zadovoljstva i psihološkog procvata}

Kako bi se odgovorilo na pitanje u kojoj mjeri zadovoljstvo poslom, smislenost posla i psihološki kapital doprinose dobrobiti nastavnika (životnom zadovoljstvu i psihološkom procvatu) u državnim i privatnim školama, provedene su dvije hijerarhijske regresijske analize. U prvom koraku uvrštene su varijable zadovoljstva poslom, smislenosti posla i psihološkog kapitala. U drugom koraku uvrštena je vrsta škole kao moderatorska varijabla. U trećem koraku za ispitivanje interakcijskog utjecaja uvrštene su tri interakcije između vrste škole i ostalih prediktorskih varijabli.U tu su svrhu standardizirani ukupni rezultati prediktorskih varijabli te stvorena nova varijabla kao njihov umnožak. Za sve navedene prediktorske varijable faktor inflacije varijabiliteta je manji od 10 , a koeficijent tolerancije veći od 0,10 što znači da ne postoji problem multikolinearnosti (Rawlings, Pantula i Dickey, 1998).

Iz Tablice 3. može se vidjeti značajan ukupni doprinos prediktorskih varijabli zadovoljstvu životom $\left(\Delta R^{2}=.215, p=.000\right)$, no statistički značajan samostalni doprinos imaju samo zadovoljstvo poslom $(\mathrm{B}=.256, \mathrm{p}=.049)$ i psihološki kapital $(\mathrm{B}=.312, \mathrm{p}=.000)$. Smislenost posla ne doprinosi značajno životnom zadovoljstvu $(B=-.070, p=.838)$. Također, ni vrsta škole ne pridonosi dodatno objašnjenju varijance životnog zadovoljstva nastavnika $\left(\Delta R^{2}=.001, p=.626\right)$. Pokazalo se i da nema značajnog ukupnog moderatorskog učinka vrste škole na vezu prediktorskih varijabli i životnog zadovoljstva $\left(\Delta \mathrm{R}^{2}=.015, \mathrm{p}=.188\right)$. Međutim, kad su u pitanju pojedinačni prediktori, vrsta škole pokazala se značajnim moderatorom u odnosu između psihološkog kapitala i zadovoljstva životom $(\mathrm{B}=-1.479, \mathrm{p}=.029)$. 
Tablica 3. Rezultati hijerarhijske regresijske analize u predviđanju životnog zadovoljstva na temelju vrste škole, zadovoljstva poslom, smislenosti posla i psihološkog kapitala

\begin{tabular}{|l|c|c|c|}
\hline Prediktor & Korak 1 (B) & Korak 2 (B) & Korak 3 (B) \\
\hline Zadovoljstvo poslom & $.611^{* *}$ & $.603^{* *}$ & $.256^{*}$ \\
Smislenost posla & .071 & .069 & -.070 \\
Psihološki kapital & $.140^{* * *}$ & $.141^{* * *}$ & $.312^{* * *}$ \\
\hline Vrsta škole (moderator) & & -.293 & -.250 \\
\hline Vrsta škole x zadovoljstvo poslom & & & .437 \\
Vrsta škole x smislenost posla & & & .284 \\
Vrsta škole x psihološki kapital & & & $-1.479 *$ \\
\hline \multicolumn{1}{|c|}{$\Delta \mathrm{R}^{2}$} & $.215^{* * *}$ & .001 & .015 \\
\hline
\end{tabular}

B - nestandardizirani koeficijenti; ${ }^{* * *} p<.001 ;{ }^{*} p<.01 ;{ }^{*} p<.05$

Kako bismo razumjeli način na koji vrsta škole mijenja smjer utjecaja psihološkog kapitala na životno zadovoljstvo, rezultate smo prikazali grafički na Slici 1 . U tu svrhu sudionici su prema razini psihološkog kapitala podijeljeni u dvije skupine, one s ispodprosječnim i s iznadprosječnim psihološkim kapitalom. Može se uočiti da i u državnim i u privatnim školama nastavnici koji imaju niži psihološki kapital imaju i niže životno zadovoljstvo. S druge strane, u državnim školama nastavnici koji imaju viši psihološki kapital imaju veće životno zadovoljstvo nego nastavnici u privatnim školama.

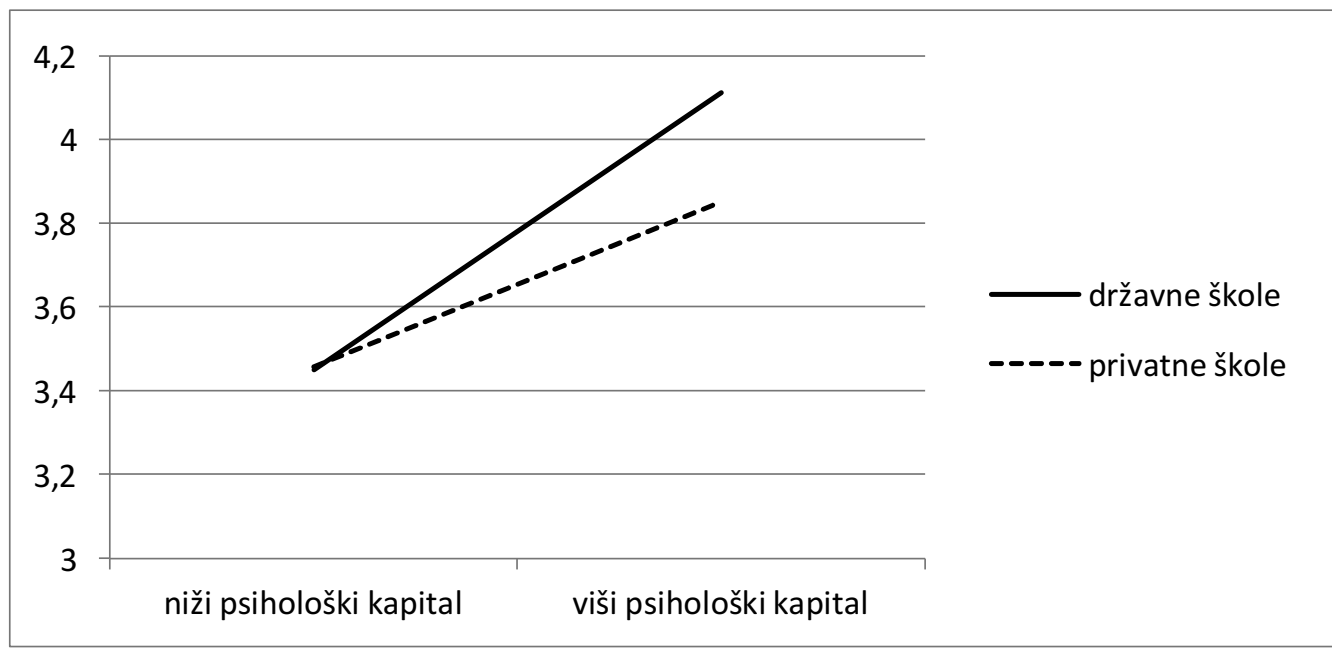

Slika 1. Moderatorska uloga vrste škole u odnosu između psihološkog kapitala i životnog zadovoljstva

Iz Tablice 4. može se vidjeti značajan ukupni doprinos prediktorskih varijabli psihološkom procvatu $\left(\Delta R^{2}=.395, p=.000\right)$, no statistički značajan samostalni doprinos imaju samo smislenost posla $(B=.766, p=.014)$ i psihološki kapital $(B=.256, p=.000)$. Zadovoljstvo poslom ne doprinosi značajno psihološkom procvatu $(B=.245, p=.408)$. Također, ni vrsta škole nije značajno povezana sa psihološkim procvatom nastavnika $(B=.271, p=.621)$. Pokazalo se da postoji 
Natalija Smrtić, Majda Rijavec

značajni ukupni moderatorski učinak vrste škole na vezu prediktorskih varijabli i životnog zadovoljstva $\left(\Delta R^{2}=.025, p=.017\right)$, ali pritom interakcija ni $s$ jednim pojedinačnim prediktorom nije značajna.

Tablica 4. Rezultati hijerarhijske regresijske analize u predviđanju psihološkog procvata na temelju vrste škole, zadovoljstva poslom, smislenosti posla i psihološkog kapitala

\begin{tabular}{|l|c|c|c|}
\hline Prediktor & Korak 1 (B) & Korak 2 (B) & Korak 3 (B) \\
\hline Zadovoljstvo poslom & .237 & .245 & .425 \\
Smislenost posla & $.228^{*}$ & $.230^{*}$ & $.766^{*}$ \\
Psihološki kapital & $.246^{* * *}$ & $.245^{* * *}$ & $.356^{* * *}$ \\
\hline Vrsta škole (moderator) & & .271 & .340 \\
\hline Vrsta škole x zadovoljstvo poslom & & & -.108 \\
Vrsta škole x smislenost posla & & & -1.054 \\
Vrsta škole x psihološki kapital & & & -1.003 \\
\hline \multicolumn{1}{|c|}{$\Delta \mathrm{R}^{2}$} & $.395^{* * *}$ & .001 & $.025^{*}$ \\
\hline
\end{tabular}

B - nestandardizirani koeficijenti; ${ }^{* *} p<.001 ;{ }^{*} p<.01 ;{ }^{*} p<.05$;

\section{RASPRAVA}

Cilj je istraživanja bio provjeriti postoje li razlike u zadovoljstvu poslom, smislenosti posla, psihološkom kapitalu na poslu i dobrobiti (životnom zadovoljstvu i psihološkom procvatu) nastavnika u privatnim i državnim školama. Dodatno, željelo se ispitati pridonose li zadovoljstvo poslom, smislenost posla i psihološki kapital dobrobiti nastavnika i je li taj doprinos vezan uz vrstu škole. Na temelju dosadašnjih istraživanja očekivalo se da će nastavnici u privatnim školama imati veći psihološki kapital i veću dobrobit, ali rezultati to nisu potvrdili. Također, u skladu s teorijskim pristupima dobrobiti očekivalo se da će psihološki kapital biti značajan prediktor obje vrste dobrobiti, dok će zadovoljstvo poslom biti prediktor zadovoljstva životom, a smislenost posla prediktor psihološkog procvata. Rezultati su potvrdili ove hipoteze.

\section{Razlike između nastavnika državnih i privatnih škola}

$\mathrm{U}$ ovom istraživanju nisu dobivene značajne razlike ni u jednoj ispitivanoj varijabli između nastavnika u državnim i privatnim srednjim školama. Nastavnici u objema vrstama škola podjednako su zadovoljni svojim poslom, percipiraju ga podjednako smislenim te imaju podjednaku razinu psihološkog kapitala i dobrobiti. lako rezultati dosadašnjih istraživanja nisu uvijek jednoznačni, u istraživanjima uglavnom nisu pronađene razlike u zadovoljstvu poslom između nastavnika u privatnim i državnim školama (Demirel, 2014; Özsoy, Uslu i Öztürk, 2014; Žužić i Miljković Krečar, 2014). Ista je situacija i kad je u pitanju smislenost posla. Rothmann i Hamukang'andu (2013) tumače to činjenicom da nastavnici općenito svoj posao doživljavaju vrlo smislenim pa je moguće da vrsta škole ne utječe na povećanje ili smanjenje smislenosti posla. $\mathrm{U}$ drugim vrstama posla zaposlenici ponekad očekuju da im poslodavac ukaže na smisao posla koji obavljaju, a budući da nema razlike u organizacijskom sistemu i postavljenim ciljevima između privatnih i državnih škola (Seco i Lopes, 2012), nema razlike ni u smislenosti posla.

Razlika nije bilo ni u razini ukupnog psihološkog kapitala na poslu. Karmakar (2016) navodi da se privatni sektor općenito više fokusira na razlike između zaposlenika i razvija njihov potencijal na temelju osobnih vještina, talenta, radnog učinka što posljedično dovodi do više 
samoefikasnosti, optimizma i nade. Međutim, moguće je da privatne i državne škole imaju iste ili slične strategije upravljanja ljudskim potencijalima pa izostaje razlika u psihološkom kapitalu.

Yılmaz i Şahin (2009) navode kako privatni sektor omogućuje viši socijalni status, veće plaće, bolju mogućnost napredovanja te bolje odnose menadžera i ostalih zaposlenika, ali moguće je da kod nastavnika te razlike nemaju značajniji utjecaj na razlike u zadovoljstvu poslom i dobrobiti ili da među školama koje su sudjelovale u istraživanju i nema velikih razlika bez obzira na to što su jedne u javnom, a druge u privatnom sektoru.

\section{Prediktori dobrobiti}

Zadovoljstvo poslom i psihološki kapital pokazali su se značajnim prediktorima životnog zadovoljstva, dok su se smislenost posla i psihološki kapital pokazali značajnim prediktorima psihološkog procvata.

Psihološki kapital najznačajniji je prediktor i zadovoljstva životom i psihološkog procvata. To je u skladu s istraživanjem koje su proveli Arab, Rezai-Badafshani i Rahimi (2015) i koje je pokazalo da nada, optimizam, psihološka otpornost i samoefikasnost djeluju na zadovoljstvo životom preko kvalitete radnog života. Psihološki kapital predviđa dobro mentalno zdravlje (Selvaraj i Bhat, 2018) koje se prema Keyesu (2002) može kategorizirati na kontinuumu od situacije kada osoba vene (engl. Languishing) preko umjerenog mentalnog zdravlja do procvata osobe (engl. Flourishing). Youssef-Morgan i Luthans (2015) navode da psihološki kapital djeluje na povećanje dobrobiti kroz optimistične atribucije, motivaciju i ustrajnost u ostvarivanju ciljeva te pozitivna očekivanja u budućnosti. S time povezane pozitivne emocije pomažu da se osoba na poslu osjeća ispunjeno i da se lakše nosi s nesigurnošću (Khan, 2013). Dakle, i dosadašnja istraživanja kao i naše pokazuju da je psihološki kapital povezan s objema vrstama dobrobiti, i sa životnim zadovoljstvom i sa psihološkim procvatom.

Zadovoljstvo poslom značajan je prediktor zadovoljstva životom dok je smislenost posla značajan prediktor psihološkog procvata. Dosadašnja istraživanja također su pokazala da zadovoljstvo poslom značajno doprinosi zadovoljstvu životom nastavnika (Aydintan i Koç, 2016; Zahoor, 2015). Nadalje, zadovoljstvo poslom povezano je $s$ drugim područjima života poput financijske situacije, obiteljskim odnosima te zdravljem što sve zajedno doprinosi zadovoljstvu životom (Loewe, Bagherzadeh, Araya-Castillo, Thieme i Batista-Foguet, 2013). Ovakvi rezultati očekivani su jer se zadovoljstvo poslom smatra specifičnom domenom subjektivne dobrobiti (Diener, Napa Scollon i Lucas, 2003) što može objasniti povezanost navedenih konstrukata. S druge strane, smislenost posla značajan je prediktor psihološkog procvata koji prema definiciji uz pozitivne odnose, osjećaj kompetentnosti i samopouzdanja uključuje i vjerovanje da je život pojedinca smislen i da ima neku svrhu (Diener i sur., 2010). Također, osobe koje svoj posao percipiraju kao smislen, pokazuju bolje mentalno zdravlje (Allan i sur., 2016). Treba napomenuti da postoje i istraživanja u kojima se smislenost posla pokazala kao prediktor i subjektivne i psihološke dobrobiti (Compton, 2000; Williamson i Geldenhuys, 2014).

Treba napomenuti da su značajni prediktori dobrobiti bili isti i u privatnim i u državnim školama, s jedinom razlikom da su u državnim školama nastavnici s višom razinom psihološkog kapitala imali veće životno zadovoljstvo nego nastavnici u privatnim školama. Dakle, ako nastavnici imaju nižu razinu psihološkog kapitala, njihovo je životno zadovoljstvo podjednako u objema vrstama škola. No, u državnim školama viši psihološki kapital povezan je s višim životnim zadovoljstvom. Teško je objasniti ovaj rezultat, ali je moguće da u državnim školama postoje specifični stresori s kojima se nastavnici s višom razinom psihološkog kapitala bolje suočavaju pa posljedično imaju i veće životno zadovoljstvo. Tako, primjerice, Hall i Chandler (2005) navode da je uspješno suočavanje vrlo značajno u situacijama kad postoje ekonomske poteškoće, a moguće je da su one češće u državnim nego u privatnim školama. 
Natalija Smrtić, Majda Rijavec

PSIHOLOŠKI KAPITAL, SMISLENOST POSLA, ZADOVOLSTVO.

\section{Prednosti, ograničenja i implikacije istraživanja}

Koliko je nama poznato, ovo je prvo istraživanje ovakvog tipa u Hrvatskoj te je temelj usporedbe s drugim zemljama u Europi i izvan nje. Za razliku od većine istraživanja kod kojih je dobrobit mjerena kao jedan konstrukt (Allan i sur., 2016; Gupta i Shukla, 2018), u ovom slučaju dobrobit je mjerena i kao zadovoljstvo životom i kao psihološki procvat čime se dobiva širi uvid u učinkovito funkcioniranje nastavnika.

Istraživanje ima i neke nedostatke. Radi se o korelacijskom istraživanju te nije moguće donositi zaključke o uzročno-posljedičnoj vezi među ispitivanim varijablama. Za dobivanje indikacija o uzročno-posljedičnoj vezi trebalo bi provesti longitudinalno istraživanje u kojem bi se u dužem vremenskom razdoblju pratila dobrobit nastavnika s različitom razinom zadovoljstva poslom, smislenosti posla i psihološkog kapitala na početku ispitivanog razdoblja. Također, moguće bi bilo u nekim školama uvesti intervencije za povećanje zadovoljstva poslom, smislenosti posla i psiholoških kapitala pa, ako intervencije budu uspješne, provjeriti promjenu dobrobiti u školama koje su prošle takve intervencije i onima koje nisu.

Nadalje, škole koje su uključene $u$ istraživanje nalaze se na području grada Zagreba što onemogućuje generaliziranje rezultata na cijelu Hrvatsku. lako se pokušao izjednačiti sastav škola u državnom i javnom sektoru, odabrane škole nisu u potpunosti reprezentativne za područje Zagreba. Istraživanje je na sjednicama Učiteljskih vijeća provođeno grupno što je moglo stvoriti pritisak nastavnicima da sudjeluju u istraživanju.

Za procjenu zadovoljstva poslom korišten je globalni pristup koji, iako je vrlo jednostavan i lako shvatljiv za sudionike, ne ispituje faktore zadovoljstva (Robbins i Judge, 2010). Ljudi se razlikuju s obzirom na način na koji procjenjuju životno zadovoljstvo (Diener i sur., 2003). Neka su područja pojedincima više, a neka manje važna te bi bilo poželjno u budućim istraživanjima ispitati i specifične faktore zadovoljstva. Iz upitnika su zbog narušavanja faktorske strukture izbačene tri negativno formulirane čestice pa se preporučuje da se u budućim istraživanjima koristi hrvatski prijevod skraćene verzije Upitnika psihološkog kapitala koji je pokazao zadovoljavajuću faktorsku strukturu (Murgić i sur., 2019).

Rezultati dobiveni u istraživanju mogu doprinijeti povećanju svijesti od strane i privatnih i državnih institucija o važnosti navedenih konstrukata i planiranju intervencija za njihovo ostvarivanje. Time bi škole povećale dobrobit zaposlenika, a posljedično i svoju konkurentnost na tržištu (Luthans i sur., 2007). Zadovoljni i sretni nastavnici mogu stvoriti pozitivno školsko ozračje koje doprinosi motivaciji učenika za učenje i aktivnost na nastavi (Vizek-Vidović, Rijavec, Vlahović-Štetić i Miljković, 2014) čime sudjeluju u kreiranju društva znanja i ekonomskom rastu države.

Bez obzira na navedena ograničenja ovo istraživanje ukazuje da zadovoljstvo poslom, smislenost posla i psihološki kapital doprinose na specifičan način različitim vrstama dobrobiti nastavnika i u privatnim i u državnim školama te tako daje nove spoznaje u povezivanju njihovog poslovnog i privatnog života.

\section{ZAKUUČAK}

Prema rezultatima istraživanja ne postoji statistički značajna razlika u psihološkom kapitalu, smislenosti posla, zadovoljstvu poslom te dobrobiti kod nastavnika s obzirom na vrstu škole. Psihološki kapital predviđa i zadovoljstvo životom i psihološki procvat. Osim navedenog, zadovoljstvo poslom je bilo značajan prediktor životnog zadovoljstva, a smislenost posla psihološkog procvata. 


\section{LITERATURA}

Allan, B. A., Dexter, C., Kinsey, R. i Parker, S. (2016). Meaningful work and mental health: job satisfaction as a moderator. Journal of Mental Health, 27(1), 38-44.

Arab, N., Rezai-Badafshani, F. i Rahimi. M. (2015). The mediating role of quality of work life between psychological capital and life satisfaction. Iranian Journal of Health Education \& Promotion, 3(1), 49-58.

Avey, J. B., Reichard, R. J., Luthans, F. i Mhatre, K. H. (2011). Metaanalysis of the impact of positive psychological capital on employee attitudes, behaviors and performance. Human Resource Development Quarterly, 22(2), 127-152.

Aydintan, B. i Koç, H. (2016). The relationship between job satisfaction and life satisfaction: An empirical study on teachers. International Journal of Business and Social Science, 7(10), 72-80.

Bakotić, D. i Bušić, J. (2014). Organizacijska predanost zaposlenika u hrvatskim poduzećima: privatni sektor vs. javni sektor. Ekonomski pregled, 65(3), 222-240.

Baş, T. i Ardıç, K. (2002). A comparison of job satisfaction between public and private university academicians in Turkey. METU Studies in Development, 29(1-2), 27-46.

Bowling, N. A., Eschleman. K. J. i Wang. Q. (2010). A meta-analytic examination of the relationship between job satisfaction and subjective well-being. Journal of Occupational and Organizational Psychology, 83(4), 915-934.

Bunderson, J. S. i Thompson, J. A. (2009). The call of the wild: Zookeepers. callings. and the doubleedged sword of deeply meaningful work. Administrative Science Quarterly, 54(1), 32-57.

Cameron, K. S., Dutton, J. E., Quinn, R. E. (2003.). Foundations of positive organizational scholarship. U: Cameron, K. S., Dutton, J. E. I Quinn, R. E. (ur.), Positive Organizational Scholarship: Foundations of a New Discipline (str. 3-13). San Francisco: Berrett-Koehler Publishers Inc.

Choi, Y. i Lee, D. (2014). Psychological capital, Big Five traits, and employee outcomes. Journal of Managerial Psychology, 29(2), 122-140.

Compton, W. C. (2000). Meaningfulness as a mediator of subjective well-being. Psychological Reports, 87(1), 156-160.

Costantini, A., De Paola, F., Ceschi, A., Sartori, R., Meneghini, A. M. i Di Fabio. A. (2017). Work engagement and psychological capital in the Italian public administration: A new resource-based intervention programme. SA Journal of Industrial Psychology, 43, 1-11.

Demirel, H. (2014). An investigation of the relationship between job and life satisfaction among teachers. Procedia - Social and Behavioral Sciences, 116, 4925-4931.

Diener, E., Emmons, R. A., Larsen, R. J. i Griffin, S. (1985). The Satisfaction with Life Scale. Journal of Personality Assessment, 49(1), 71-75.

Diener, E., Napa Scollon, C. i Lucas, R. E. (2003). The evolving concept of subjective well-being: the multifaceted nature of happiness. Advances in Cell Aging and Gerontology, 15, 187-219. Amsterdam: Elsevier.

Diener, E., Wirtz, D., Tov, W., Kim-Prieto, C., Choi, D., Oishi, S. i Biswas-Diener, R. (2010). New wellbeing measures: Short scales to assess flourishing and positive and negative feelings. Social Indicators Research, 97(2), 143-156.

Državni zavod za statistiku Rebublike Hrvatske (2018). Priopćenje - Srednje škole. kraj šk. g. 2015./2016. i početak šk. g. 2016./2017. Zagreb: Državni zavod za statistiku Republike Hrvatske. Preuzeto s https://www.dzs.hr/Hrv_Eng/publication/2017/08-01-03_01_2017.html, 3.7.2018.

Duckworth, A.L., Quinn, P.D. i Seligman, M. E. P. (2009). Positive predictors of teacher effectiveness. The Journal of Positive Psychology, 4(6), 540-547.

Faragher, E. B., Cass, M. i Cooper, C. L. (2005). The relationship between job satisfaction and health: A meta-analysis. Occupational and Environmental Medicine, 62(2), 105-112.

Gupta, D. i Shukla, P. (2018). Role of psychological capital on subjective well-being among private sector female employees. Indian Journal of health and Well-being, 9(5), 740-744.

Hall, D. T. i Chandler, D. E. (2005). Psychological success: When the career is a calling. Journal of Organizational Behavior, 26(2), 155-176. 
Hansen, A., Buitendach, J. H. i Kanengoni, H. (2015). Psychological capital, subjective well-being, burnout and job satisfaction amongst educators in the Umlazi region in South Africa. SA Journal of Human Resource Management, 13(1), 1-9.

Henderson, L. W. i Knight, T. (2012). Integrating the hedonic and eudaimonic perspectives to more comprehensively understand wellbeing and pathways to wellbeing. International Journal of Wellbeing, 2(3), 196-221.

Huppert, F. i So, T. (2013). Flourishing across Europe: Application of a new conceptual framework for defining well-being. Social Indicators Research, 110(3), 837-861.

Janik, M. i Rothmann, S. (2015). Meaningful work and secondary school teachers' intention to leave. South African Journal of Education, 35(2), 1-13.

Karmakar, R. (2016). Positive psychological capital: Does this promote the use of functional and dysfunctional coping strategy? International Journal of Applied Research, 2(4), 22-27.

Keyes, C. L. M. (2002). The mental health continuum: From languishing to flourishing in life. Journal of Health and Social Behavior, 43(2), 207-222.

Khan, I. (2013). Psychological capital and happiness among government and private bank employees - A comparative investigation. Indian Journal of Applied Research, 3(2), 336-338.

$\mathrm{Li}, \mathrm{Y}$. (2018). Building well-being among university teachers: theroles of psychological capital and meaning in life. European Journal of Work and Organizational Psychology, 27(5), 1-9.

Loewe, N., Bagherzadeh, M., Araya-Castillo, L., Thieme, C. i Batista-Foguet, J. (2013). Life domain satisfactions as predictors of overall life satisfaction among workers: Evidence from chile. Social Indicators Research, 118(1), 71-86.

Luthans, F. (2002). Positive organizational behavior: Developing and managing psychological strengths. Academy of Management Executive, 16(1), 57-72.

Luthans, F., Avolio, B. J., Avey, J. B. i Norman, S. M. (2007). Positive psychological capital: Measurement and relationship with performance and satisfaction. Personnel Psychology, 60(3), 541-572.

Luthans, F., Youssef, C. M. i Avolio, B. J. (2007). Psychological capital: Developing the human competitive edge. New York: Oxford University Press.

Miljković, D., Jurčec, L. i Rijavec, M. (2016). The relationship between teachers' work orientations and well-being: mediating effects of work meaningfulness and occupational identification. U: $Z$. Marković, M. Đurišić Bojanović \& G. Đigić (ur.), Individual and Environment: International Thematic Proceedia (str. 303-312). Niš, Serbia: Faculty of Philosophy.

Murgić, D., Rijavec, M. i Miljković, D. (2019) Inicijalna validacija skraćenog upitnika psihološkog kapitala (UPK-12) na hrvatskom uzorku. Ekonomski pregled, 71(1), 3-21.

Rawlings, J. O., Pantula, S. G. i Dickey, D. A. (1998). Applied regression analysis: A research tool. New York: Springer Science \& Business Media.

Rijavec, M. (2015). Treba li sreću poučavati u školi? Croatian Journal of Education, 17(1), 229-240.

Rijavec, M., Ljubin Golub, T., Olčar, D. (2016). Can learning for exams make students happy? Faculty related and faculty unrelated flow experiences and well-being. Croatian Journal of Education, 18(1), 153-164.

Rijavec, M., Brdar, I. i Miljković, D. (2006). Extrinsic vs. Intrinsic Life Goals, Psychological Needs, and Well-Being. U: A. Delle Fave (ur.). Dimesions of well-being: Research and inteventions. Milano: FrancoAngeli.

Robbins, S. P. i Judge, T. A. (2010). Organizacijsko ponašanje. Zagreb: Mate.

Rosso, B. D., Dekas, K. H. i Wrzesniewski, A. (2010). On the meaning of work: A theoretical integration and review. Research in Organizational Behavior, 30, 91-127.

Rothmann, S. i Hamukang'andu, L. (2013). Callings, work role fit, psychological meaningfulness and work engagement among teachers in Zambia. South African Journal of Education, 33(2), 1-16.

Ryan, R. M. i Deci, E. L. (2001). On happiness and human potentials: A review of research on hedonic and eudaimonic well being. Annual Review Of Psychology, 52, 141-166.

Özsoy, E., Uslu, O. i Öztürk, O. (2014). Comparing private and public sector employees' job and life satisfaction: A developing country sample. International Journal of Recent Advances in Organizational Behaviour and Decision Sciences, 1(2), 1-8. 
Seco, V. i Lopes, M. P. (2012). Professionals calling in lifelong learning centers. Journal of Industrial Engineering and Management, 6(2), 668-685.

Selvaraj, P. R. i Bhat, C. S. (2018). Predicting the mental health of college students with psychological capital. Journal of Mental Health, 27(3), 279-287.

Shahnawaz, M. G. i Hassan Jafri, M. H. (2009). Psychological capital as predictors of organizational commitment and organizational citizenship behaviour. Journal of the Indian Academy of Applied Psychology, 35, 78-84.

Steenkamp, P. L. i Basson, J. S. (2013). A meaningful workplace: Framework, space and context, Theological Studies, 69(1), 1-9.

Tov, W. i Diener, E. (2013). Subjective well-being. Research Collection School of Social Sciences, 1395, $1-7$.

Tummers, L. G. i Knies, E. (2013). Leadership and meaningful work in the public sector. Public Administration Review, 73(6), 859-868.

Vizek-Vidović, V., Rijavec, M., Vlahović-Štetić, V. i Miljković, D. (2014). Psihologija obrazovanja. Zagreb: IEP-Vern.

Waterman, A. S. (1993). Two conceptions of happiness: Contrasts of personal expressiveness (eudaimonia) and hedonic enjoyment. Journal of Personal and Social Psychology, 64(4), 678-691.

Watson, D., Clark, L. A. i Tellegen, A. (1988). Development and validation of brief measures of positive and negative affect: The PANAS scales. Journal of Personality and Social Psychology, 54(6), 1063-1070.

Whittington, J. L., Meskelis, S., Asare, E. i Beldona, S. (2017). Enhancing employee engagement: An evidence-based approach. New York: Palgrave-Macmillan.

Williamson, J. C. i Geldenhuys, M. (2014). Positive work experiences and life satisfaction: the moderating role of gender. Journal of Psychology in Africa, 24(4), 315-320.

Yılmaz, E. i Şahin, M. (2009). A study into life satisfaction levels of the teachers working at primary education in terms of some variables. E-Journal of New World Science Academy, 4(4), 14041414.

Youssef-Morgan, C. M. i Luthans, F. (2015). Psychological capital and well-being. Stress Health. 31(3), 180-188.

Zahoor, Z. (2015). A comparative study of psychological well-being and job satisfaction among teachers. Indian Journal of Health and Wellbeing, 6(2), 181-184.

Žužić, I. i Miljković Krečar, I. (2014). Zadovoljstvo poslom kod nastavnika privatnog i javnog visokog učilišta. Napredak, 154(1-2), 119-138.

\title{
Psychological Capital, Meaningfulness of Work, Job Satisfaction and Well-Being of Teachers in Private and Public Schools
}

\begin{abstract}
The aim of the study was to assess differences in job satisfaction, work meaningfulness, psychological capital and well-being in private and public school's teachers. Furthermore, the aim was to asses the contribution of job satisfaction, work meaningfulness and psychological capital to teachers' well-being in both types of schools. Participants were 152 teachers from public schools and 100 teachers from private schools in Zagreb. The measures included Work Meaningfulness Scale, PsyCap Questionnaire, Satisfaction with Life Scale and Flourishing Scale. For measuring global job satisfaction one-item scale was used. Results have shown that there was no statistically significant difference between public and private school's teachers in any of the measured variables. Job satisfaction was significant predictor of life satisfaction, while work meaningfulness was for flourishing. Psychological capital positively contributes to both life satisfaction and flourishing. The results theoretically contribute to understanding factors that contribute to teachers' well-being in public and private schools and can help in designing interventions for creating a positive environment that will improve teachers' well-being.
\end{abstract}


Keywords: job satisfaction, psychological capital, teachers in public and private schools, well-being, work meaningfulness

\section{Psychologisches Kapital, Sinnhaftigkeit der Arbeit, Arbeitszufriedenheit und Wohlbefinden der Lehrer an privaten und öffentlichen Schule}

Zusammenfassung: Das Ziel der Untersuchung war, die Unterschiede im Hinblick auf die Arbeitszufriedenheit, die Arbeitsbedeutsamkeit, das psychologische Kapital und das Wohlbefinden bei Lehrern an privaten und staatlichen Schulen festzustellen, sowie den Beitrag der Arbeitszufriedenheit, der Arbeitsbedeutsamkeit und dem psychologischen Kapital zum Wohlbefinden von Lehrern in beiden Schultypen zu untersuchen. 152 Lehrer an staatlichen Schulen und 100 Privatschullehrer beteiligten sich an der Untersuchung. Als Messinstrumente wurden der Fragebogen zum psychologischen Kapital, die Skala zum Sinn der Arbeit, die Skala zur Lebenszufriedenheit und die Skala zum psychologischen Wohlstand verwendet. Die globale Arbeitszufriedenheit wurde mit nur einem Item gemessen. Die Ergebnisse zeigten, dass es in den untersuchten Variablen keinen bedeutsamen Unterschied gibt zwischen Lehrern, die an staatlichen Schulen arbeiten, und Lehrern, die an Privatschulen arbeiten. Die Arbeitszufriedenheit war ein signifikanter Prädiktor für die Lebenszufriedenheit, und die Arbeitsbedeutsamkeit war ein signifikanter Prädiktor für das Wachstum. Das psychologische Kapital trägt positiv der Lebenszufriedenheit und dem Wachstum bei. Die Ergebnisse liefern einen theoretischen Beitrag zum Verständnis der Wohlfahrtsfaktoren für Lehrer in privaten und staatlichen Schulen und können zur Gestaltung von Interventionen beitragen, um ein positives Umfeld zu schaffen, welches das Wohlbefinden verbessert.

Schlüsselwörter: Arbeitszufriedenheit, Arbeitsbedeutsamkeit, Lehrer an privaten und staatlichen Schulen, psychologisches Kapital, Wohlbefinden 